\title{
The Rhetorical Construction of Corporate Logos
}

\section{La Construcción Retórica de los Logos Corporativos}

\author{
CARMEN Llorente-BARRoso \\ Universidad CEU San Pablo (CEU San Pablo University). \\ carmen.llorentebarroso@ceu.es - carmenllore@gmail.com \\ FrANCISCO GARCÍA-GARCÍA \\ Universidad Complutense de Madrid (Complutense University of Madrid). \\ fghenche@gmail.com
}

Recibido: April 9th, 2014

Aprobado: July 18th, 2014

\begin{abstract}
This research is set in the context of today's societies, in which the corporate visual symbology of a business, corporation or institution constitutes an essential way to transmit its corporate image. Traditional discursive procedures can be discovered in the development of these signs. The rhetorical strategies developed by the great classical authors appear in the logo-symbols expressing the corporate values of today's companies. Thus, rhetoric is emerging once again in the sense it had many centuries ago: A repertory of rules that, paradoxically, standardizes the deviations of language and whose control is synonymous with power. The main objective of this study is to substantiate the rhetorical construction of logos using as a model of analysis the classical process of creating discourse. This involves understanding logos as persuasive discourses addressed to a modern audience.

Our findings show that the rhetorical paradigm can be considered as a creative model for the construction of an original logo consistent with a company's image.

Keywords: Corporate visual symbology, rhetoric, rhetorical strategies, logo-symbols, logo, company's image.
\end{abstract}

Llorente-Barroso, C., García-García, F. (2015): The Rhetorical Construction of Corporate Logos. Arte, Individuo y Sociedad, 27(2) 257-277

\section{Resumen}

Esta investigación se contextualiza en las sociedades actuales, en las que la simbología visual corporativa de una empresa, corporación o institución constituye una forma esencial de transmitir su imagen corporativa. En el desarrollo de estos signos visuales se descubren procedimientos discursivos tradicionales. Aquellas estrategias retóricas que desarrollaron los grandes autores clásicos aparecen en los logo-símbolos que expresan los valores corporativos de las actuales empresas. De esta manera, la retórica vuelve a emerger en el sentido que se le dio hace siglos; un repertorio de reglas que normalizan, paradójicamente, los desvíos del lenguaje y cuyo control es sinónimo de poder. El objetivo principal de esta investigación es comprobar la construcción retórica de los logos utilizando como modelo de análisis el proceso clásico de creación del discurso. Esto supone entender los logos como discursos persuasivos dirigidos a un moderno auditorio.

Los resultados obtenidos permiten considerar el paradigma retórico como un modelo creativo para la construcción de un logo original y coherente con la imagen de la empresa.

Palabras clave: Simbología visual corporativa, retórica, estrategias retóricas, logo-símbolos, logo, imagen corporativa. 
Contents: 1. Introduction: From Classical Rhetoric to Applied Visual Rhetoric, 2. Methodology, 2.1. Analysis Model, 3. Results, 4. General Discussion and Conclusions, 4.1. Testing of Hypothesis. References.

\section{Introduction: From Classical Rhetoric to Applied Visual Rhetoric}

Under the broad umbrella of the term "corporate image," the subject of this research study is the logo-symbol (Villafañe, 1999), popularly known as logotype, and in our case understood as the visual and symbolic representation of an organization's identity. These visual signs, known in "signography" as emblematic, incorporate in their meaning all the associations that accompany the brand (Stötzner, 2003). In this sense, a logo is a sign of a symbolic nature with its own autonomy, whose construction is based on some of the connotations of the expressive elements that constitute it (García García, Llorente Barroso \& García Guardia, 2010).

Of all the many types of logos in existence, we focus here on the ones that represent for-profit organizations. Our analysis is carried out from a rhetorical perspective that considers the whole set of rhetorical procedures contained in the logo-symbols in the persuasive, symbolic, and visual representation of a firm.

Corporate image and corporate visual identity (CVI) are areas that have been intensely investigated by authors such as Villafañe $(1993,1999)$ and González Solas (2002). Nonetheless, even though some of these authors have recognized the existence of a rhetorical code in the midst of corporate visual design (González Solas, 2002; Moles \& Costa, 1999), none of them has made an exhaustive analysis of this field.

Given the rhetorical perspective from which we approach our research subject, a brief run through the most important theories of rhetoric is in order. Classical rhetoric set the foundations of discourse building, the most important contributions coming from Aristotle (1959), Cicero (1991, 1998) and Quintilian (1963). After a long run of lethargy brought on by its bad reputation, rhetoric emerged forcefully once more in the middle of the twentieth century. This renewal of rhetoric (neo-rhetoric) entailed a resurgence of that lost discipline thanks to the contributions of Perelman \& Olbrechts-Tyteca (1958), Lausberg (1998), Barthes (1964, 1966, 1970), Todorov (1966), Genette (1966, 1970), Eco (1970), Durand (1970) and Ricoeur (1975).

In recent years, some authors have warned of the lack of attention that rhetoric has received in the context of higher education (Olson, 2007), even in the specific training subjects of business communication (Brumberger, 2005). Nonetheless, the importance of rhetoric is determined by its own survival. "It hasn't died," but has adapted to each communicative context; it survives because it is still an essential model for studying effective communication (De Marchis, 2013).

The development of digital communication has led to the creation of new rhetorical contents and profiles that make it possible to adapt discourse to new needs (García García, 2005). Thus, rhetoric applied to information technologies permits more persuasive and effective communication in online spaces such as social networks (Berlanga, 2013). What is more, "rhetorical figures" are interpreted as creative subroutines that permit the building of interactive advertising formats and recover a means of contact with the target that are necessary in online platforms (Llorente Barroso, 2013). 
Today, moving beyond the specific field of discourse, the rhetorical perspective has served to better understand what neuroscientists call "visual imagery" and its capacity to alter sensory perception (Hawhee, 2011).

Within the general study of rhetoric, special attention has been given to analyzing the elocutionary virtue of ornatus (adornment), particularly metaphor (Kennedy \& Kennedy, 1993). This explains the development of theories devoted to its analysis, such as the Conceptual Metaphor Theory or CMT (Lakoff \& Johnson, 1980) and the Contemporary Theory of Metaphor or CTM (Lakoff, 1993; Ruiz de Mendoza Ibáñez \& Pérez Hernández, 2011).

In the field of advertising, linked to that of corporate image and visual identity, the rhetorical perspective has been developed relatively in depth. The research field of discursive elaboration, Fernández (2006) and Sánchez Corral (1991) posit a general analysis of the rhetorical construction process in advertising. In line with this trend, García García (2007) stated that the expressive potential of the advertising message is the result of rhetorical procedures. From a similar orientation, Ruiz Collantes (2000) proposes creative rhetoric as a model of advertising creativity for "thinking up texts in advertising".

Certain authors are of the opinion that research into visual rhetoric can contribute to a better understanding and interpretation of advertising (Bulmer \& BuchananOliver, 2006). In this sense, Lagerwerf, Hooijdonk \& Korenberg (2012) studied how visual rhetoric may be involved in cognitive processes and the meaning of graphic advertising. They analyzed two meaning operations, "connection," which associates two visual elements, and "similarity," which establishes that one element is like another. They conclude that "connections" elicit more open interpretations, whereas "similarities" are more likely to promote cognitive elaboration (Lagerwerf et al., 2012). Other contributions in the context of advertising rhetoric have focused specifically on adornment. This is not surprising considering that some of the most important creative techniques for constructing advertising discourse are based on this rhetorical virtue (Llorente, 2011). In this vein, Jeong (2008) evaluated the persuasive effects of visual metaphors in advertising messages, concluding that advertisements with visual metaphors can be more persuasive than advertisements with literal images and verbal anchoring. These results lend support to the idea of "visual persuasion" put forward by Messaris (1997), who considers that viewers are more persuaded by visual arguments with implicit suggestions since they require greater cognitive elaboration and are more readily accepted (Jeong, 2008). In a similar vein, Ortiz (2010) analyzed the presence of primary metaphors in graphic advertising and discovered that certain primary metaphors give rise to visual structures characterized by Symmetric Object Alignment (SOA). In this regard, Schilperoord, Maes \& Ferdinandusse (2009) identify SOA as a visual rhetorical scheme used in advertisements to establish a metaphorical or associative relation. Their analysis led them to differentiate between two types of formal elements in the architecture of SOA: The constituent factors of the objects (size, form and color), and the representative (or perceptive) factors of the objects (perspective, orientation, distance from the point of visualization) (Schilperoord et al., 2009).

That said, the visual specification on which we focus here also requires a look at some of the key contributions to the development of a visual rhetoric, among which 
we highlight the following:

a) The work by structuralist authors such as Barthes (1964) or Durand (1970), who carried out specific analyses based on conceptual transitions from the linguistic to the visual field.

b) The work Traité du signe visuel: Pour une rhétorique de l'image by Groupe $\mu$ (1992), which advocates the creation of a general rhetoric of images and criticizes the reductionism of the structuralists, by giving the image the same status as the word.

c) The contributions of R14 (Icono14), a research group led by García García $(2005,2007)$ and devoted to research in aesthetics, the image, communication, and information technologies from a poetical and rhetorical perspective.

Within this framework, the general aim of the present study is to uncover the rhetorical strategies and procedures involved in the process of creating a logo-symbol, with the ultimate goal of helping graphic design and corporate image professionals to create the most effective corporate visual symbols from the persuasive point of view, regardless of their expressive form.

Thus, the work summarized in this article maintains the hypothesis that the paradigm of classical rhetoric persists as a creative model in the construction of original logo-symbols.

\section{Methodology}

We used a qualitative methodology that involves discourse analysis and a systematic register of the data in categories. The analysis is based on a closed model constructed from previous recognized theories that is applied systematically to a sample consisting of several units (logo-symbols). This permits an ordered accumulation of data that makes it possible to extract frequencies and trends.

The delimitation of the material universe of the study, in this case comprised of the logo-symbols that represent the identitary essence of for-profit organizations, has led to a sample whose units satisfy two selection criteria, which in order of importance are as follows:

1. Socio-cultural repercussion or impact: The criterion that determines the effectiveness of logo-symbolic discourses.

2. Diversity and representativeness: This criterion takes three factors into account:

a) The different expressive possibilities that a logo-symbolic discourse can have, according to the nomenclature proposed by Villafañe (1999) (logotype (exclusively typographic), symbol (exclusively visual), or logo-symbol (a combination of logotype and visual symbol)).

b) The heterogeneity of commercial sectors in a global market to which a logosymbol may refer.

c) The capability of logo-symbolic discourse to generate spatial-temporal identities.

The definitive sample is comprised of a total of nine units, three of each of the expressive type of logo-symbols that can be found in the material universe that is the object of study, according to the classification made by Villafañe (1999). It is not a matter of analyzing a representative sample of reality, because we do not consider in relative terms the proportion of each of the expressive types existing in the material 
universe in question. On the contrary, as explained earlier, this sample is intentionally balanced in order to accomplish the aims formulated above.

The sample is thus comprised of the logo-symbols of Coca-Cola, La Caixa, and DreamWorks, the logotypes of IBM, eBay, and Telefónica, and the symbols of Nike, Apple and Versace.
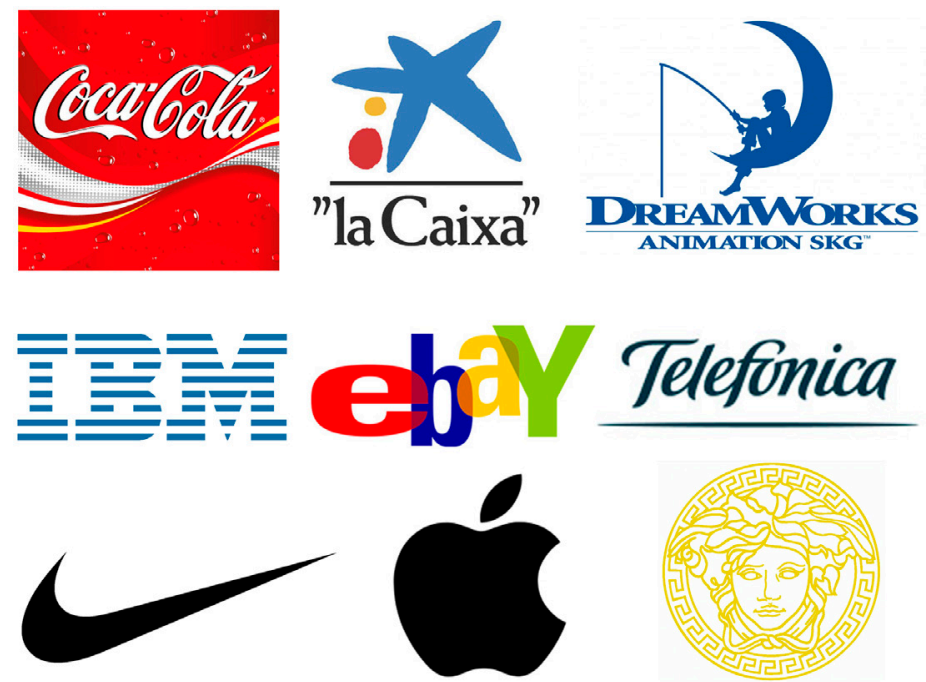

Figure 1. Sample analyzed. Source: The authors based on the images by Peter-Paul [IC1K] (2008), Vector Logotypes (2012), Logonoid (n.d.), Rehman (2012), Dunn (2009), Telefónica (n.d.), Oeilsj (2011), Royal (2011) and Famous logo, jaguars logo (2013).

\subsection{Analysis Model}

Each of these units is analyzed through the systematic application of a model. This model is based on the four theoretical perspectives of rhetoric taken throughout its history:

1. The theories developed by the classical theorists, especially by Aristotle (1959), Cicero $(1991,1998)$ and Quintilian (1963), which set out the main principles of this discipline.

2. The conceptual renewal of rhetoric that took place in the mid-twentieth century, especially thanks to the contributions of Perelman \& Olbrechts-Tyteca (1958) and Lausberg (1998) in the linguistic and literary context.

3. The contributions provided by Groupe $\mu$ (1982, 1992), Barthes (1964) and Durand (1970), who began to apply the principles of linguistic rhetoric to visual substances.

4. The most recent contributions regarding rhetoric applied to images, advertising and digital media. Among these we would highlight R14 (Icono14), directed by Professor García García (2005; 2007), those by Fernández (2006) and those by Sánchez Corral (1991). 


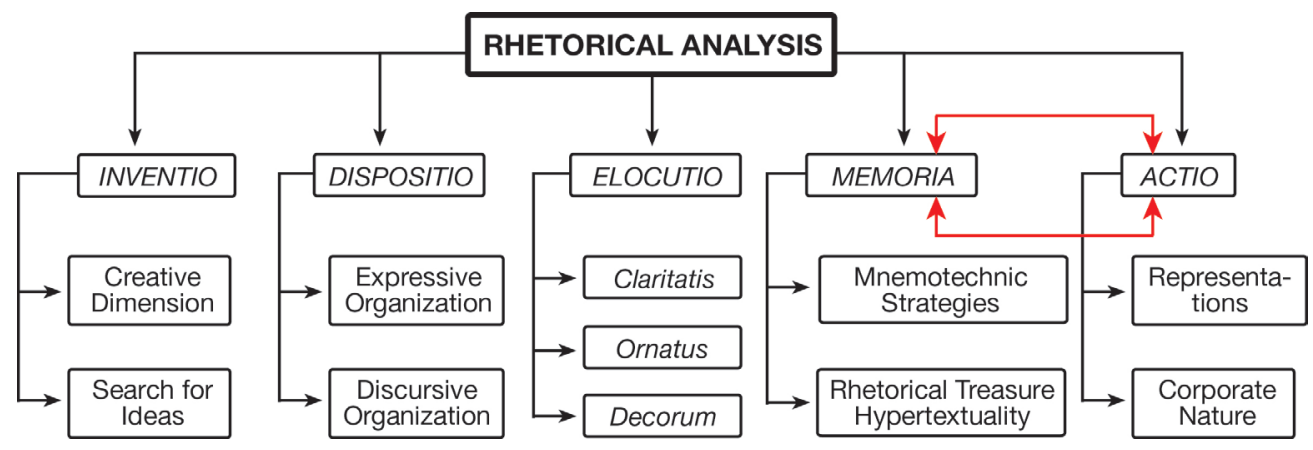

Figure 2. Model of Analytical Application. Source: The authors.

In this way we develop a model based on a set of units of analysis that will permit a thorough study of the rhetorical construction of logo-symbolic discourse. These units are as follows:

1. Inventio (quid dicamos): This is understood as a search for the most likely arguments for the best visual representation of the brand in question. This part of the analysis addresses the study of the different discursive parts that the logo-symbol manifests according to the differentiation made by classical theory: Exordium (introductory part of the logo-symbolic discourse which is meant to capture the audience's attention); narratio (the conceptual contents contained in the visual sign that correspond to the corporate image of the brand in its Gestaltic conception (Villafañe, 1993)); argumentatio (the pathetic, ethical and real proofs that can be found in the logo-symbol for the defense of the brand it represents); and peroratio (conclusion of the logo-symbolic discourse).

2. Dispositio (sed etiam quo loco): This unit focuses on analysis of the organization of the discourse as manifested in the logo-symbol, with a dual perspective: An expressive one, that refers to the arrangement of the elements that make up the logo as a visual whole, and another one of content, which refers to the order (ordo naturis or artificialis) of the parts of the discourse.

3. Elocutio (quo modo dicamus): Analysis of this unit consists of studying the expressive form of the logo-symbolic discourse which, according to rhetorical precepts, must be what best suits both the contents of the discourse proposed and the peculiarities of the audience it is addressed to. This rhetorical stage is analyzed through each of the elocutionary virtues: Claritatis (clarity), analyzed from an expressive and conceptual perspective; ornatus (adornment), a virtue studied not only as a virtue for attaining the expressive beauty of the logo-symbol, but also as a fundamental strategy for achieving the full corporate meaning of the logo-symbolic discourse; decorum (decorum), a virtue analyzed as the relation the brand develops with its customers and which is manifested in its discourse of visual representation.

4. Memoria: Analysis of memoria is carried out considering its two dimensions: On one hand, understanding memoria as a repertory of mnemotechnic strategies, and on the other hand, considering it as a depository of the rhetorical treasure. In this second meaning, memoria is analyzed in relation to the concepts of "hypertextuality" 
and "hypotextuality" (Genette, 1982: 12-13), which in turn are linked to the rhetorical meaning of "paraphrase" (Llorente Barroso, Anzanello Carrascoza \& García Guardia, 2011).

5. Actio or pronuntiatio (apte dicere): This parameter is studied as the set of different possibilities in which the brand pronounces its logo-symbolic discourse, taking into account the decorum, the characteristics of the audience to which the discourse is addressed, the peculiarities of the media through which it is presented and the expressive possibilities the brand allows its visual discourse to have.

\section{Results}

The frequencies, trends and intensities extracted from the overall interpretation of the results determine that the logo-symbols are discourses that manifest characteristics typical of the demonstrative and deliberative classical genres (the demonstrative genre praises the brand it represents, seeking to delight its audience with impactful elocution, whereas the deliberative genre seeks to elicit in the audience addressed a favorable attitude towards the brand it represents), but no evidence points to the judicial or forensic classical genres.

Furthermore, there are other results of interest if we focus on each unit of analysis:

1. Inventio: The construction of any effective logo-symbol requires a search for the arguments that best represent the company or brand visually. In this regard there is a set of storehouses (loci) of best practices that have worked on other occasions. Nonetheless, each logo-symbol should be a new and unique visual discourse that, despite being based on pre-existing ideas, has an originality that will allow a differentiated expression of the brand it represents.

As discourse, the logos analyzed here show a different visual structure that is often the result of the evolution and adaptation of the logo-symbol itself. Regardless of their expressive form (Villafañe, 1999), the logos analyzed in our sample show all the discursive parts synthesized into two, exordium and peroratio. The synthesis of the logo-symbolic discourse to these two parts is a response to the need for immediacy and brevity that governs their transmission. Responding to the logic of the logo-symbolic code, the exordium manifests in its form of principium (direct) and as auditorem attentum parare, when it constitutes itself as a direct call for attention from the receiver.

Narratio and argumentatio are synthesized in expressive nuances with great symbolic potential (especially in corporate symbols). Therefore the brand must develop a parallel means of corporate communication that will permit a better understanding of the logo-symbolic discourse and which is determinant when presenting a logo for the first time. This parallel communication helps to build a narratio between fabula (manifested in the poetical beauty of the discourse and in its symbolic potential) and historia (present in the symbolic references to the company or its socio-economic reality). The narratio of the logo is the contents contained in the set of visual stimuli that make up its signifier. This content is connotative and only insinuated visually; it is built up over time and is related to the concept of corporate image. The conceptual complexity of this narration lies in its dynamism and intangibility, since it not only varies over time in line with market demands, 
but also changes according to each viewer. The construction of the logo-symbolic narratio forms part of the intentional image of a company (Villafañe, 1999), that is, the company controls it. For its part, the argumentatio is manifested in an even more synthesized way. Built upon pathetic and real proofs, it is generated through the corporate communication associated with the logo. Thus, the logo-symbolic discourse seeks to associate itself with emotions, passions and feelings (pathos), but also with the actual situation of the company and brand it represents (logos). Nonetheless, argumentation is determined by the symbolic potential of colors, shapes and sometimes textures.

If we take as an example the logo-symbol of Coca-Cola, narration and argumentation are suggested discursive parts, which appear when evoked by the visual stimuli that comprise it. The Coca-Cola logo-symbol does not have enough time to tell a story about a company that makes soft drinks. However, certain small details can be observed in this logo-symbol that refer to the company's behavior, culture and personality. Thus, the bubbles provide a description of the star soft drink of the brand (corporate behavior), whereas the dynamic waves, the color red and the evolved calligraphy of Frank Robinson refer to some of the values that the brand defines on its corporate website (The Coca-Cola Company, n.d.), in particular those of leadership, passion, and diversity.

The argumentatio of this logo is based on pathetic proofs, since it is especially meant to move the passions of the viewers it is addressing; in fact, the corporation itself considers passion to be one of the values on which its intentional image is built (Villafañe, 1999).

Peroratio is the other outstanding part of logo-symbolic discourse, which is summarized (due to the demands of the language it belongs to) as a call for attention and a conclusion of what the company wishes to show, influencing the emotions of the viewers.

2. Dispositio: From an expressive point of view, the dispositio of a logo-symbol depends on the elements that make up the expressive set that constitutes it, that is, of its character as logotype, symbol, or logo-symbol (Villafañe, 1999). Of these three expressive possibilities, the only one that is expressively complete is the last one, which is the one that determines a natural logo-symbolic discourse from a formal perspective. It must be said that some logo-symbols can alternate the arrangement of their expressive elements according to the communicative medium in which they appear or the specific area of the company they represent. One example of this would be the logo-symbol of La Caixa.

In regard to discursive content, the dispositio of a logo-symbol depends both on the discursive parts that are shown in it and how they are arranged. Thus, all the logo-symbols analyzed show an ordo naturalis (a natural and logical order) only in the sense that they somehow present all the discursive parts, even though the logosymbolic discourse is actually reduced to an exordium and a peroratio, since narratio and argumentatio appear only in suggested form. Moreover, all the parts of the discourse, implicit and explicit, are manifested simultaneously and without following a precise and determined order, which is why they constitute ordo artificialis (artificial order) discourses. 
3. Elocutio: This is one of the most important parts in the construction of a logo, since it consists of giving an attractive form to the contents of the logo-symbolic discourse. Besides being in charge of adapting the contents of the logo-symbolic discourse to the most suitable expression, the elocutio of each logo should attain the expressive form most in keeping with the profile of the audience of the company or brand it represents. This is the audience to whom the discourse is addressed. Elocution contains the poetics of the corporate visual discourse, and to a great extent, its ability to attract and persuade.

The rhetorical elocutio of any logo must represent the true identitary essence of the company, making it beautiful without falsifying it, and respecting the three fundamental virtues that must govern it (claritatis, ornatus, and decorum). Of the inferences observed in the analysis of elocutio, the following can be highlighted:

a) Claritatis: This is one of the most highly recommended virtues in logo-symbolic discourse; a clear logo makes it easier for the viewer to remember it. However, the clarity of the elocutio shown in the logo-symbols analyzed here tends to be disturbed in two fundamental ways. On one hand, in regard to the name of the brand, which it either expresses (if it has an exclusively typographic element) or else evokes (if there is no exclusively typographic element). Whether or not a typographic element is present, they refer to a name whose construction is based on barbarisms, neologisms or metaplasms:

- As neologisms: The name of the brand they evoke and represent always contains a new dimension of meaning, of a corporate nature and completely different from the ones that word had previously. Thus, Nike is not the Greek goddess of victory, but the brand that produces, distributes and commercializes sports products, even though her name is used to take advantage of her symbolic values.

- As barbarisms: The names of almost all brands sin against grammatical puritas since they are generally words that are non-existent in the vocabulary of any language, the result of a corruption in spelling. In the case of Ebay, the nominal construction of the brand name combines the letter $e$ (the abbreviation of electronic, used to refer to online activity) and the word bay. The result is a barbarism or linguistic vice that does not precisely follow the rules of English.

- As metaplasms: Sometimes a brand name is the result of linguistic upsets that are occasionally justified by mere aesthetics, and at other times respond to mnemotechnics so viewers will remember the brand name. An example that combines both justifications is that of Coca-Cola, since its name is composed of two pre-existing words (coca leaves and kola nuts), one of which has been changed. In the brand name, kola has been changed to cola, which means we have a metaplasm and a partial grammatical vice (barbarism) corresponding to poetical visual play (paranomasia); furthermore, the repetition of the first syllable of each word comprising the brand name makes it easier for people to remember it (COca-COla).

Also to be considered is that although the language used by companies to determine their brand name offers descriptive data about their geographical origin, it may put non-speakers of that language at a disadvantage in terms of correct pronunciation and interpretation. This disadvantage is another impediment to the clarity of a logosymbol. This is what occurs in Spain with brands such as Apple (English) or in non- 
Spanish-speaking countries with brands such as Telefónica (Spanish) or La Caixa (Catalan).

In another vein, some of the logos analyzed resort to visual forms that pre-date the existence of the company. Although the signifiers of these forms show a high degree of iconicity with a referent from reality (the case of Apple), in these cases the signifiers refer to companies, and therefore the relation between signifier and referent is actually non-existent. These logos take advantage of the symbolic load of the images mentioned to reach their full meaning, although the meaning of the corporate visual sign takes on a new, specifically corporate, semantic dimension that heretofore did not form part of any of the images making up the logo-symbol.

Thus, logos evoke much more complex meanings, making them signs of great ambivalence.

Sometimes logos are constructed out of simpler visual forms, and this simplicity promotes the expressive clarity of the logo-symbol, making it easier to remember (the case of Nike). Other times, they are constructed according to an over-elaborate ornatus that can make it easier to recall due to differentiation, since although it gives rise to a form of important expressive complexity, this complexity is the basis of its discriminating originality (the case of Versace).

b) Ornatus: This is the virtue that permits poetry; limited by decorum, its aim is to beautify, but to be effective the designer must have an absolute command of logo-symbolic language and its resources. The power of ornatus in a logo-symbol lies in its definition as an accumulation of rhetorical strategies that not only make the discourse more beautiful, but also confer full corporate meaning on it. We analyzed ornatus using the outline of rhetorical tropes provided by Durand (1970):

\begin{tabular}{|c|c|c|c|c|}
\hline \multirow{2}{*}{$\begin{array}{l}\text { RELATION } \\
\text { BETWEEN } \\
\text { VARYING } \\
\text { ELEMENTS }\end{array}$} & \multicolumn{4}{|c|}{ RHETORICAL OPERATION } \\
\hline & Addition & Suppression & Substitution & Exchange \\
\hline Identity & Repetition & Ellipsis & Hyperbole & Inversion \\
\hline $\begin{array}{l}\text { Similarity } \\
\text { - of form } \\
\text { - of content }\end{array}$ & $\begin{array}{l}\text { Rhyme } \\
\text { Comparison }\end{array}$ & Circumlocution & $\begin{array}{l}\text { Allusion } \\
\text { Metaphor }\end{array}$ & $\begin{array}{l}\text { Hendiadys } \\
\text { Homology }\end{array}$ \\
\hline Difference & Accumulation & Suspension & Metonymy & Asyndeton \\
\hline $\begin{array}{l}\text { Opposition } \\
\text { - of form } \\
\text { - of content }\end{array}$ & $\begin{array}{l}\text { Zeugma } \\
\text { Antithesis }\end{array}$ & $\begin{array}{l}\text { Dubitation } \\
\text { Reticence }\end{array}$ & $\begin{array}{l}\text { Paraphrase } \\
\text { Euphemism }\end{array}$ & $\begin{array}{l}\text { Anacoluthon } \\
\text { Chiasmus }\end{array}$ \\
\hline $\begin{array}{l}\text { False similarity } \\
\text { - Ambiguity } \\
\text { - Paradox }\end{array}$ & $\begin{array}{l}\text { Antanaclasis } \\
\text { Paradox }\end{array}$ & $\begin{array}{l}\text { Tautology } \\
\text { Preterition }\end{array}$ & $\begin{array}{l}\text { Pun } \\
\text { Antiphrasis }\end{array}$ & $\begin{array}{l}\text { Antimetabole } \\
\text { Antilogy }\end{array}$ \\
\hline
\end{tabular}

Table 1. General classification of rhetorical operations according to Durand (1970).

Source: The authors based on Durand (1970). 
The most interesting results at the poetic level are achieved when more than one code is used (in the complete logo-symbols). The characteristics of logo-symbolic language determine a preference for the rhetorical operations of suppression and substitution. Nonetheless, the figures of addition and exchange are often used as the constructive foundation of such discourses, especially in those using a single code (logotypes or symbols). The trend, frequencies and intensities we found led to the following main conclusions:

- Among the figures of substitution the tropos stand out, the most important being allusion, hyperbole, and synecdoche. In fact, a logo-symbol, whatever its type, is a hyperbolic synecdoche built on allusion and metaphor. As synecdoche it represents a whole (the company (physical reality) and the corporate image (conceptual reality) based on one of its parts, its visual signature (the logo-symbol). As hyperbole, it endows the expression of the brand with magnanimity, symbolically enlarging its true corporate identity by resorting to allusions and metaphors. Of the tropos mentioned, the ones that are used to achieve meaning (Quintilian, 1963), metaphors and synecdoches, are the most determinant in the construction of the full meaning of the logo-symbol, whereas those used to achieve adornment (Quintilian, 1963), allusions and hyperboles, seek a way to delight the audience. As examples, we have the logos of Ebay, Apple, and La Caixa. In the Ebay logotype the typographic form, thick and straight, transmits the stability and security (Jury, 2006; Ambrose \& Harris, 2011) one wants in a company specializing in e-commerce and online auctions. However, the disorganized internal arrangement of the letters contains a symbolic metaphor of the freedom on which Ebay wants to base its commerce. This freedom is supported by the chromatic richness, although the alternation between warm and cold colors metaphorically evokes values linked to those colors. Thus, the warm colors express proximity (Chevalier \& Gheerbrant, 1994; Heller, 2004) to a user with whom there is no physical contact, whereas the cold colors reinforce the seriousness linked to the thick straight lines of the letters, transmitting confidence, an essential value for a firm based on economic transactions. The popular Apple symbol was used in the first seal of the company (Fig. 3) which, designed by Ronald Wayne in 1976, showed Isaac Newton under an apple tree at the moment the apple is falling on his head, providing him with the key to gravity. Immediately after the appearance of this seal, in 1977 Rob Janoff created the chromatic rainbow apple with a bite taken out that appeared on the Apple II. This symbol was considered by many to be in homage to two of Newton's most important discoveries: The law of gravity (the apple shape) and the decomposition of white light into its color spectrum (the rainbow colouring). However, in Western culture the apple is also linked to desire and its prohibition (Cirlot, 1997), that is, the symbol of the Apple brand is also a symbol of temptation. 

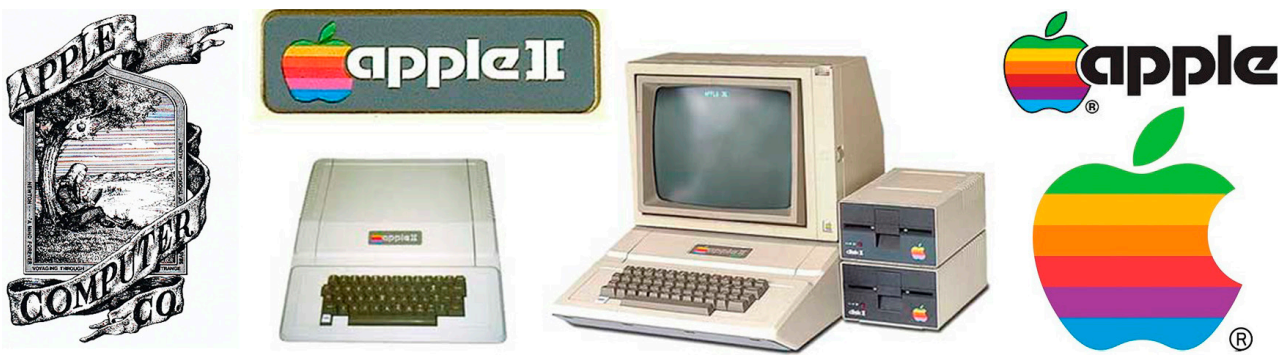

Figure 3. Original seal of Apple (1976) and logo-symbol of Apple II (1977). Source: The authors, based on images by Old Computers (n.d.) and Dernbach (2011).

The logo-symbol of La Caixa emerged as an accumulation of symbolic metaphors referring to contrasting and implicitly combined concepts. The symbol part of this logo-symbol is taken from a tapestry by Spanish artist Joan Miró and expresses his typical artistic style and that of the Mediterranean culture of the company. This visual part contrasts with the typographic part since it transmits opposing values. The irregular form and polychromatism typical of Mirós art is combined with the stability and sobriety of the typography in order to add the serious nature of banking to Mediterranean values.
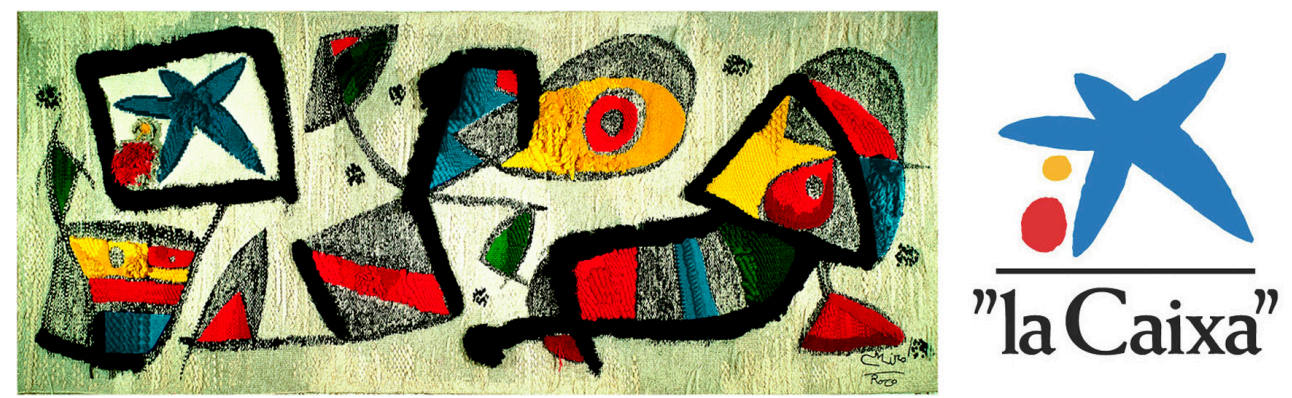

Figure 4. The Miró tapestry from which the logo-symbol of La Caixa was taken. Source: The authors based on images from La Caixa (n.d.).

- When it comes to the suppression element of elocutio, the perception of rhetorical figures requires a greater capacity for abstraction, especially when there is a single code, since a more complex and interpretative reading is required. Nonetheless, it is worth mentioning the important presence of ellipsis, since all the logo-symbols analyzed here make up a discourse that is very limited in expression, despite their connotative capacity.

- Figures of addition (adjunctio) are rhetorical strategies that particularly stand out in complete logo-symbols, although certain figures of addition can be considered the constructive foundation of any logo, where the accumulation of elements of the same style but with differences in the expressive and conceptual details stands out for its persistence or significance. Also significant are the conceptual antitheses generated 
by hooks explained by chromatics (Nike), shape (La Caixa), and occasionally, texture (IBM). In this last case, the antithesis generated between the absence and presence of the shape is a basic tool in the emergence of the most characteristic visual element of the IBM logtype: Its striped texture.

- Rhetorical figures of exchange are ornamental strategies particularly present in the logos made from the two codes that logo-symbolic language permits. In general, the most important figures because of their constructive character are the following: Asyndeton, as the accumulation of different elements with no copulative nexus between them; and homology, in the complete logo-symbols in which each code is presented as an analogue of the other (Dreamworks), although they are not strict homologies, since each part of the discourse tends to contribute something new and different to the logo as a whole.

c) Decorum: In charge of governing ornatus or adornment, this virtue has a determinant effect on memoria and actio, the rhetorical stages most closely linked to the audience. To the extent that it conforms to the deal that the company is offering to its audience, it becomes a cross-sectional identitary trait, and is therefore reflected in each of its manifestations, including the logo-symbol. As a cross-sectional rhetorical virtue it demands that the logo designer have a thorough knowledge of the company in question and also its customer base, or the audience it wishes to address.

4. Memoria: The overall interpretation of the results allows us to determine the following:

a) That when memoria is understood from its perspective as a repertory of mnemotechnic strategies that make it easier for the audience to assimilate and recall the logo, as well as its association with the conceptual type that it evokes:

- Simplicity and clarity in form and/or color and/or texture favor recall of the logo-symbol.

- The use of certain rhetorical figures, such as formal repetitions, metaphors and allusions, help people to recognize the expression of the brand and to understand the meaning of the logo associated with an expressive whole.

b) That when memoria is understood as a depository of rhetorical treasure, there are clear links with actio and the concept of "hypertextuality" (Genette, 1982), in turn related to the rhetorical concept of "paraphrase" (Llorente Barroso et al., 2011). Moreover, as a rhetorical storehouse, the memoria of all logo-symbols is a "hypotext" of the subsequent logos that take their expressive or conceptual ideas from it, and a "hypertext" of the logos it takes as an expressive or conceptual point of reference. These "transtextual" relations, defined by Genette (1982), can be established either from imitation of an expressive style which evokes a different conceptual content, or from the simple transformation of that style while maintaining the content. The significant trajectory of most of the logos selected for our sample tends to elevate them to the status of "hypotexts," although in all cases we detected traces that convert them into "hypertexts" of previous ones. In the analysis of the "hypertextuality" of each logo-symbol within the same brand, we considered the two strategies (imitation and simple transformation) described by Genette (1982): 
- Transformation. In this case, the "hypertextuality" is generated by the historical evolution of the logo-symbol, which gradually changes its expressive style, either to accommodate a new commercial context or to adhere to new corporate values, but maintaining a basically stable content. Thus, the first logo used by the company becomes the original "hypotext," the point of reference for the rest that emerged later and which generally become its "hypertexts." Two examples we can cite are the logos of Nike and IBM (Fig. 5), the expressive evolution being most evident in the latter case.

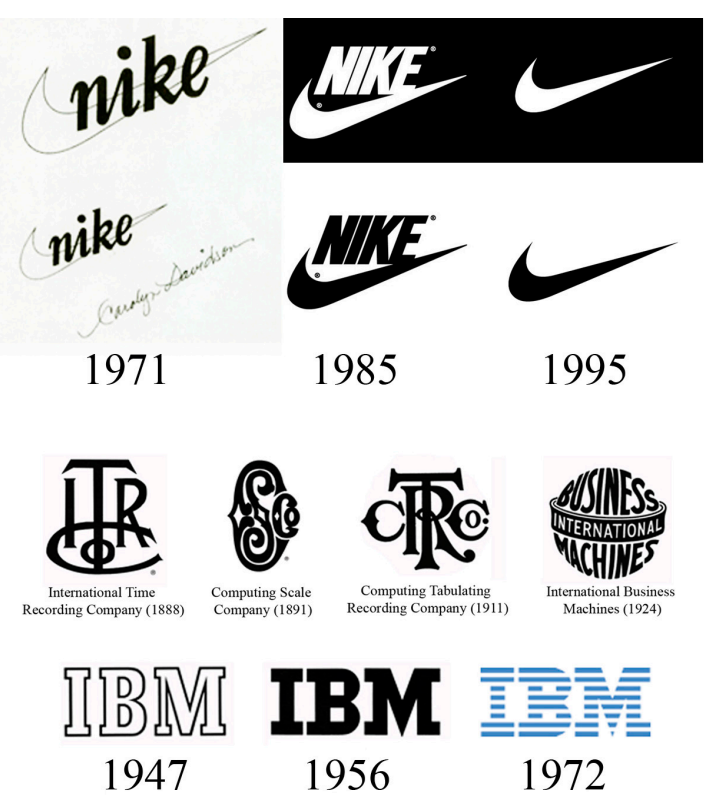

Figure 5. "Hypertextual" evolution of the Nike logo and "Hypertextual" evolution of the IBM logo. Source: The authors based on images by Karenh (2011), The World's Best Ever (2011) and Santoso (2008).

- Transformation and imitation. In this case, a "hypertextual" relation is observed between the logo-symbol of a brand and all the other elements that go into its corporate visual identity, such that these elements can be understood as "hypertexts" by simple transformation of the logo-symbol (the basis of the CVI), since they always refer to the same conceptual content (the corporate image of the company), but also as "hypertexts" by imitation, since they maintain an expressive similarity with the logosymbol. In this sense, Coca-Cola's famous "contour bottle" has become just one more element of its identity; its evolution (The Coca-Cola Company, 2012) is synonymous with the evolution of the brand itself, as can be seen in Fig. 6. 


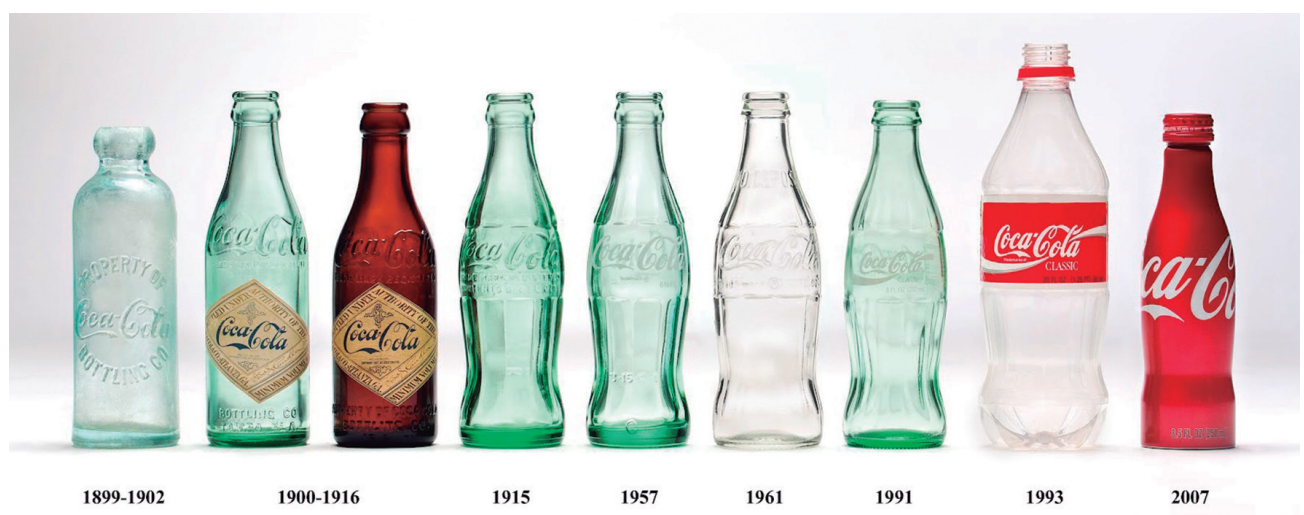

Figure 6. "Hypertextual" evolution of the contour bottle. Source: The Coca-Cola Company (2012).

Understood in this way, the memoria of a logo-symbol manifests the trajectory of the visual expression of a specific brand from the time it comes into existence, moreover determining its particular contribution to a general corporate visual culture which it helps to create and enrich.

5. Actio or pronuntiatio: The representation of the logo-symbolic discourse must consider the following:

a) The decorum of the company it represents, since this is what guides its representation.

b) The characteristics of the audience to whom the discourse is addressed.

c) The peculiarities of the formats used to present the logo-symbolic discourse and the media through which it is transmitted.

d) The expressive possibilities that the company permits in its different forms of visual and symbolic representation, which are generally standardized in a manual of corporate visual identity.

The code governing logo-symbols does not allow the orator (designer) to introduce changes in line with the reactions of the audience, as orator and audience in this case do not share a physical space at the time of the actio or representation speech. Moreover, any change would involve a significant financial investment on the part of the company and studies to determine the foreseeable results, as each change in the logo of a brand means a disturbance in the stability of its image and this involves a considerable risk (Villafañe, 1999; Stuart \& Muzellec, 2004). This risk reflects the fact that changes in corporate identity symbols rarely have a positive impact on corporate image (Dowling, 2002). In fact, "If there is no apparent reason for the logo change, it will either go unnoticed (which is hardly cost-effective), or will be regarded with suspicion" (Stuart \& Muzellec, 2004: 477). Therefore the "clear break away from the past" (Muzellec \& Lambkin, 2006: 815) that the development of corporate rebranding strategies involves should respond to very good reasons (Stuart \& Muzellec, 2004).

Like the orators of old, today's designers show a mood or disposition to their audiences through the works they create. However, in the case of logo-symbols, this 
disposition has to be sifted through the decorum the company wishes to reflect, since in the end it is the company's logo, even though a professional designer has been charged with constructing it.

\section{General Discussion and Conclusions}

The analysis described above was approached from an Aristotelian point of view that considers rhetoric a multidisciplinary science to be used in all situations, since knowledge of it is available to all, unlike that of a defined science (Aristotle, 1959).

Seen from this perspective, logo-symbolic language is constructed as a form of persuasive communication, a parallel and alternative code that transgresses a very weak semiotics. This rhetorical language is the result of the new conception of rhetoric that was developed to adapt the classical concept of rhetoric to current pragmatic and social situations of communications (Perelman \& Olbrechts-Tyteca, 1958). This renovation of rhetoric meant coming to the understanding that all discourse is developed in consideration of the characteristics of an audience that it wishes to convince and persuade in some way. Nevertheless, in the case of visual rhetoric, a more specific adaptation was needed. In classical times the image proper was considered a rhetorical figure of thought with great emotional charge, but often useless because of its excessive ornamental poetics addressed to praise or vituperation (Cicero, 1991). Today, however, we cannot conceive of life without images; the persuasive potential of certain visual discourses has led to consideration of the visual code in its rhetorical dimension. Like classical rhetoric, corporate visuality based on symbols and rhetoric emerged from a practical necessity in a society that demanded a specific type of persuasive enunciation: The logo-symbol. As a form of persuasive communication, corporate visual rhetoric is conscious of its audience in all its stages, but especially in inventio, elocutio, actio and memoria, the rhetorical stages related to the creation, expression, representation and recall of the logo-symbol.

Despite the difficulties involved in such an ambiguous code, because of its symbolic essence, the aims of docere (to show), delectare (to delight), and movere (to mobilize) are clear. The visual attraction contained in these discourses delights at the same time that it shows a hidden discourse, knowledge of which tends to mobilize our passions and desires. For this reason logo-symbols take shape as discourses analogous in their aims to what the classical theorists created and developed and to what appears in advertising (Fernández, 2006). They are rhetorical discourses that oblige us to assume a degree of connotation in which the true sense of the discourse resides.

In light of the above, the complete meaning of a logo-symbol at first seems to be complex and unattainable, but certain expressive forms allow us to glimpse a symbolic meaning that, especially when first encountered, needs a parallel and more explicit communication to allow the receiver to assimilate its complete meaning. Thus, corporate designers have become modern orators, often without being aware of the rhetorical techniques that they nonetheless apply, even unconsciously, in doing their job: The creation of a logo. 


\subsection{Testing of Hypothesis}

The results obtained in this study allow us to confirm the starting hypothesis: The paradigm of classical rhetoric persists as a creative model in the construction of original logo-symbols.

In all of the discourses analyzed we have been able to differentiate to a greater or lesser extent the presence of the different discursive modes classified by rhetorical precepts (exordium, narratio, argumentatio and peroratio), although exordium and peroratio stand out because of their potency and because of the properties of the logosymbolic code. The necessary immediacy which logos are subject to means that they have to be direct and brief discourses, and their discursive content is limited to two essential parts, one that attracts the attention of the public, and one that, by way of conclusion, determines the content of the discourse. Narratio and argumentatio are implicit parts that will be evoked symbolically from the same expressive elements that determine the exhortation and conclusion of the logo.

The verification of this hypothesis means that designers of corporate logos will be able to use classical rhetoric as a source of creative strategies in order to construct an original and effective logo-symbol destined to represent a brand and persuade consumers. Logos could therefore be created by following the same model of creative process that an orator uses to build a classic speech. Thus, the orator-designer must first seek out ideas for constructing the discourse by looking for originality, to wit, the important creative dimension of inventio. Secondly, in dispositio, the designer organizes those ideas according to a structure that, albeit chaotic, manifests all the parts proper to rhetorical discourse, with the possibility of opting for three different expressive possibilities (complete logo-symbol, logotype, or symbol). Thirdly, the designer must then adapt the discourse to the most suitable expression, both in terms of its content and the characteristics of the audience to which it is addressed, resorting to the most appropriate elocutio and guided by the virtues of clarity, adornment, and decorum. In fourth place, the designer must consider the mnemotechnic strategies that will help the public to assimilate and remember the visual stimuli that shape the expression of the discourse, and to associate them with the conceptual type (corporate image) and the referent (the company or brand) that it represents. This furthermore helps to generate the logo-symbolic memoria, that is, a corporate visual culture that reflects the particular trajectory of the visual expression of the brand and that helps to construct a general corporate visual culture. In this case, memoria shows a strong connection with actio and with the concept of "hypertexutality" (Genette, 1982) linked to the rhetorical notion of "paraphrase." Finally, the logo designer has to consider the different possibilities of representation that the created discourse can manifest, by analyzing its actio. These possibilities, currently collected in a CVI program because of their role in determining the stability of a corporate image, are different from those the classical orator faced. This is due to the characteristics of the code and the media used in logo-symbols, which mean that the logo designer (and by extension, the brand) cannot vary the representation according to the reactions observed in the audience, since as mentioned, unlike the classical orators, they do not share a physical space in the discourse representation. 


\section{References}

Ambrose, G. \& Harris, P. (2011). The fundamentals of typography. Lausanne: AVA Academia.

Aristotle. (1959). The "art" of rhetoric. Trans. by J. H. Freese. London: W. Heinemann.

Barthes, R. (1970). L'ancienne rhétorique: Aide-mémoire. Communications, 16, 172223.

Barthes, R. (1966). Recherches sémiologiques: L'analyse structurale du récit. Communications, 8, 1-27.

Barthes, R. (1964). Rhétorique de l'image. Communications, 4, 40-50.

Berlanga, I. (2013). Retórica clásica y redes online: Dos realidades convergentes y análogas. Perspectivas y prospectivas de 9 expertos en comunicación. Icono14, 11(1), 45-70. doi: 10.7195/ri14.v11i1.548.

Bulmer, S. \& Buchanan-Oliver, M. (2006). Visual rhetoric and global advertising imagery. Journal of Marketing Communications, 12(1), 49-61. doi: $10.1080 / 13527260500289142$.

Brumberger, E. R. (2005). Visual rhetoric in the curriculum. Pedagogy for a multimodal workplace. Business Communication Quarterly, 68(3), 318-333. doi: $10.1177 / 1080569905278863$.

Chevalier, J. \& Gheerbrant, A. (1994). A dictionary of symbols. Oxford: Blackwell.

Cicero (1998). De inventione. Trans. by M. Greco. Galatina: Congedo.

Cicero (1991). Rhetorica ad Herennium / Retórica a Herenio. Trans. by J. F. Alcina. Barcelona: Bosch.

Cirlot, J. E. (1997). Diccionario de símbolos (2nd ed.). Madrid: Siruela.

De Marchis, G. P. (2013). Retórica, tecnología y sociedad. Presentación. Icono14, 11(1), 01-04. doi: 10.7195/ri14.v11i1.571.

Dernbach, C. (2011, October 30). Apple history in pictures. The start 1976 - 1984. Photo gallery [blog post]. Retrieved March 4, 2014, from http://www.mac-history. net/photo-gallery/2011-10-30/apple-history-in-pictures-the-start-1976-1984

Dowling, G. (2002). Corporate reputations. Identity, image, and performance. New York: Oxford University Press.

Dunn, S. (2009, November 4). More fonts used in logos of popular websites [blog post]. Retrieved March 4, 2014, from http://buildinternet.com/2009/11/morefonts-used-in-logos-of-popular-websites/

Durand, J. (1970). Rhétorique et image publicitaire. Communications, 15, 70-95.

Eco, U. (1970). Sémiologie des messages visuels. Communications, 15, 11-51.

Famous logo, jaguars logo. (2013, March 22). All Versace logos [blog post]. Retrieved March 6, 2014, from http://jaguarslogo.blogspot.com.es/2011/01/all-versacelogos.html

Fernández, E. (2006). Retórica clásica y publicidad. Logroño: Instituto de Estudios Riojanos (Gobierno de La Rioja).

García García, F. (2005). Una aproximación a la historia de la retórica. Icono14, 3(1), 1-28. doi: 10.7195/ri14.v3i1.426

García García, F. (2007). Una retórica de la publicidad: De la naturaleza inventiva a la verdad metafórica. Pensar la Publicidad, 1(2), 167-182. 
García García, F., Llorente Barroso, C. \& García Guardia, M L. (2010). La construcción globalizada del logo-símbolo y la globalización de la marca a través del mismo. Historia y Comunicación Social, 15, 131-156.

Genette, G. (1966). Frontières du récit. Communications, 8, 152-163.

Genette G. (1970). La rhétorique restreinte. Communications, 16, 158-171.

Genette, G. (1982). Palimpsestes: La littérature au second degré. Paris: Seuil.

González Solas, J. (2002). Identidad visual corporativa: La imagen de nuestro tiempo. Madrid: Síntesis.

Groupe $\mu$ (1982). Rhétorique générale. París: Seuil.

Groupe $\mu$ (1992). Traité du signe visuel: Pour une rhétorique de l'image. Paris: Seuil.

Hawhee, D. (2011). Looking into Aristotle's eyes: Toward a theory of rhetorical vision. Advances in the History of Rhetoric, 14(2), 139-165. doi: 10.1080/15362426.2011.613288.

Heller, E. (2004). Psicología del color. Cómo actúan los colores sobre los sentimientos y la razón. Barcelona: Gustavo Gili.

Jeong, S. H. (2008). Visual metaphor in advertising: Is the persuasive effect attributable to visual argumentation or metaphorical rhetoric? Journal of Marketing Communications, 14(1), 59-73. doi: 10.1080/14697010701717488.

Jury, D. (2006). What is typography? Mies: RotoVision.

Karenh (2011, August 4). Swoosh: 40 years fly by [blog post]. Retrieved March 4, 2014, from http://blog.mattsung.com/post/8486241616/nike-swoosh-brand-logodesign-40-years-later?ref=nf

Kennedy, V. \& Kennedy, J. (1993). A special issue: Metaphor and visual rhetoric. Metaphor and Symbolic Activity, 8(3), 149-151.doi:10.1207/s15327868ms0803_1.

La Caixa. (n.d.). Corporate information. History of La Caixa [website]. Retrieved March 9, 2014, from http://www.lacaixa.com/informacioncorporativa/historia en.html

Lagerwerf, L., Hooijdonk, C. M. J. \& Korenberg, A. (2012). Processing visual rhetoric in advertisements: Interpretations determined by verbal anchoring and visual structure. Journal of Pragmatics, 44(13), 1836-1852. doi: 10.1016/j. pragma.2012.08.009.

Lakoff, G. (1993). The contemporary theory of metaphor. In Ortony, A. (Ed.), Metaphor and thought (2nd ed., pp. 202-251). Cambridge: Cambridge University Press.

Lakoff, G., \& Johnson, M. (1980). Metaphors we live by. Chicago: University of Chicago Press.

Lausberg, H. (1998). Handbook of literary rhetoric: A foundation for literary study. Trans. by M. T. Bliss \& A. Jansen. Leiden; Boston; Köln: Brill.

Llorente, C. (2011). El carácter retórico de la construcción creativa en publicidad. En F. García García y M. Rajas. (Eds.) (2011). Narrativas audiovisuales: Los discursos, 2 (pp. 339-374). Madrid: Icono14 Editorial.

Llorente Barroso, C. (2013). Tippexperience: El ornato como fuente creativa para la construcción de formatos publicitarios innovadores en YouTube. Icono14, 11(1), 71-98. doi: 10.7195/ri14.v11i1.514. 
Llorente Barroso, C., Anzanello Carrascoza, J. y García Guardia, M. L. (2011). Paráfrase e memória: Estratégias persuasivas do discurso publicitário contemporáneo. Comunicação, Mídia e Consumo, 8(22), 65-98.

Logonoid. (n.d.). Dreamworks logo [blog post]. Retrieved March 6, 2014, from http://logonoid.com/dreamworks-logo/

Messaris, P. (1997). Visual persuasion: The role of images in advertising. London: Sage.

Moles, A \& Costa, J. (1999). Publicidad y diseño. Buenos Aires: Infinito.

Muzellec, L. \& Lambkin, M. (2006). Corporate rebranding: Destroying, transferring or creating brand equity? European Journal of Marketing, 40(7/8), 803-824. doi: $10.1108 / 03090560610670007$.

Oeilsj (2011, February 22). A little on Nike - logo, tagline and advertising [blog post]. Retrieved March 4, 2014, from http://oeilsj.wordpress.com/2011/02/22/alittle-on-nike-logo-tagline-and-advertising

Old Computers. (n.d.). Apple II - 1977 by Apple Computer [website]. Retrieved March 9, 2014, from http://oldcomputers.net/appleii.html

Olson, L. C. (2007), Intellectual and conceptual resources for visual rhetoric: A reexamination of scholarship since 1950. The Review of Communication, 7(1), 1-20. doi: 10.1080/15358590701211035.

Ortiz, M. J.(2010). Visual rhetoric: Primary metaphors and symmetric object alignment. Metaphor and Symbol, 25(3), 162-180. doi: 10.1080/10926488.2010.489394.

Perelman, Ch. \& Olbrechts-Tyteca, L. (1958). Traité de l'argumentation: La nouvelle rhétorique. Bruxelles: Presses Universitaires de France.

Peter-Paul [IC1K]. (2008, September 26). Coca-cola logo [blog post]. Retrieved March 6, 2014, from http://www.ipernity.com/doc/64436/3048410

Quintilian. (1963). The institutio oratoria of Quintilian. Trans. by H.E. Butler. London: William Heinemann; Cambridge: Harvard University Press.

Rehman, A. (2012, August 16). 10 best collection of IBM logo designs [blog post]. Retrieved March 9, 2014, from http://takedesigns.com/ibm-logo/

Ricoeur, P. (1975). La métaphore vive. Paris: Seuil.

Royal, C. (2011, October 6). Honoring Steve: Apple-logo-black [blog post]. Retrieved March 4, 2014, from http://tech.cindyroyal.net/?attachment id=1322

Ruiz Collantes, F. X. (2000). Retórica creativa: Programas de ìdeación publicitaria. Bellaterra: Universitat Autònoma de Barcelona (Servei de Publicacions); Castelló de la Plana: Publicacions de la Universitat Jaume I; Barcelona: Universitat Pompeu Fabra; València: Universitat de València (Servei de Publicacions).

Ruiz de Mendoza Ibáñez, F. J. \& Pérez Hernández, L. (2011). The contemporary theory of metaphor: Myths, developments and challenges. Metaphor and Symbol, 26(3), 161-185. doi: 10.1080/10926488.2011.583189.

Sánchez Corral, L. (1991). Retórica y sintaxis de la publicidad (itinerarios de la persuasión). Córdoba: Servicio de Publicaciones de la Universidad de Córdoba.

Santoso, A. (2008, February 7). The evolution of tech companies' logos [blog post]. Retrieved March 9, 2014, from http://www.neatorama.com/2008/02/07/theevolution-of-tech-companies-logos/ 
Schilperoord, J., Maes, A. \& Ferdinandusse, H. (2009). Perceptual and conceptual visual rhetoric: The case of symmetric object alignment. Metaphor and Symbol, 24(3), 155-173. doi: 10.1080/10926480903028110.

Stötzner, A. (2003). Signography as a subject in its own right. Visual Communication, 2(3), 285-302. doi: 10.1177/14703572030023003.

Stuart, H. \& Muzellec, L. (2004). Corporate makeovers: Can a hyena be rebranded? Journal of Brand Management, 11(6), 472-482. doi: 10.1057/palgrave. bm.2540193.

Telefónica. (n.d.). Telefónica brands [website]. Retrieved March 4, 2014, from http:// www.telefonica.com/en/telefonica brands/at identidad marcas telefonica.shtml

The Coca-Cola Company. (n.d.). Mission, vision and values [website]. Retrieved March 9, 2014, from http://www.thecoca-colacompany.com/ourcompany/ mission vision values.html

The Coca-Cola Company. (2012). Coca-Cola stories: Bottles [website]. Retrieved March 9, 2014, from http://www.coca-colacompany.com/stories/coca-colastories-bottles

The World's Best Ever (2011, August 5). The Nike swoosh was designed for $\$ 35$ back in 1971 [blog post]. Retrieved March 9, 2014, from http://www.theworldsbestever. com/2011/08/05/the-nike-swoosh-was-designed-for-35-back-in-1971/?utm source $=$ feedburner\&utm medium $=$ feed\&utm_campaign $=$ Feed $\% 3 \mathrm{~A}+$ theworlds $\overline{\mathrm{b}}$ estever+\%28The+World $\% 27 \mathrm{~s}+$ Best + Ever $\% 3 \overline{\mathrm{A}}+$ on + what + matters $\% 29$

Todorov, T. (1966). Les catégories du récit littéraire. Communications, 8, 125-151.

Vector Logotypes. (2012, May 20). La Caixa vector logo download [blog post]. Retrieved March 4, 2014, from http://vectorlogotypes.net/logo/36457_La_Caixa. htm

Villafañe, J. (1999). La gestión profesional de la imagen corporativa. Madrid: Pirámide.

Villafañe, J. (1993). Imagen positiva: Gestión estratégica de la imagen de las empresas. Madrid: Pirámide. 
